\title{
THE HERMENEUTICAL APPROACH IN TRANSLATION STUDIES
}

\author{
Bernd Stefanink* \\ Universität Bielefeld/Universitatea Babeş Boliay din Cluj \\ Ioana Bălăcescu** \\ Universitatea din Craiova
}

\begin{abstract}
Our aim is to convince the reader of the validity of the hermeneutical approach in translation studies. In a first part, we will show that this validity is based on the fact that the hermeneutical approach integrates factors like subjectivity, intuition, corporeality and creativity in its theoretical reflection, being thus close to the reality of the translation process. In a second part, we will situate this approach in the context of the development of modern translation studies since the 1950s, and show that this development was characterized by a dominating tendency that led from an atomistic to a more and more holistic view of the translation unit, legitimating the holistic approach, which is fundamental in translational hermeneutics. Our third part relates the history of philosophical hermeneutics as the legitimate foundation of translational hermeneutics. In a fourth part, devoted to the "outcoming perspectives", we will try to reinforce the legitimacy of the hermeneutical approach by showing how
\end{abstract}

\footnotetext{
* Professor at University of Bielefeld. Since 2007 research and teaching fellow of the Herder Foundation/DAAD. From Aug. 2015 - July 2016: visiting Professor at Universidade Federal de Santa Catarina/Brazil. E-mail: bstefanink@hotmail.com

** PhD in Traduction: didactique et créativité" (University of Craiova; 2005). 2006-2007: Humboldt foundation post-doc research scholarship at TU Darmstadt and Bielefeld University (Supervisors Radegundis Stolze and Bernd Stefanink). Lecturer at Craiova University/Romania, Department of Applied Linguistics. E-mail: ioanadi@hotmail.com
} 
it is supported by recent results of research in cognitive science. In order to foster further research in translational hermeneutics we also offer a methodology based on hermeneutic principles to study the translation process. Finally, we give an example of legitimation of a creative problemsolving based on a hermeneutical approach of a translation problem which finds its validation in the results of cognitive research.

Keywords: Translational hermeneutics. Subjectivity in translation. Creativity in translation. Translatology. Cognitive science.

\section{A ABORDAGEM HERMENÊUTICA EM ESTUDOS DE TRADUÇÃO}

Resumo: Nosso objetivo é convencer o leitor da validade da abordagem hermenêutica em estudos de tradução. Na primeira parte, demonstraremos esta validade, baseados no fato de que a abordagem hermenêutica integra fatores como a subjetividade, a intuição, a corporalidade e a criatividade em sua reflexão teórica, aproximando-se, portanto, da realidade do processo tradutor. Na segunda parte, situaremos esta abordagem no contexto do desenvolvimento dos estudos modernos de tradução desde os anos 1950, e mostraremos que este desenvolvimento foi caracterizado por uma tendência dominante, que levou de uma visão atomista da unidade de tradução a uma visão mais holística, legitimando-a, o que é fundamental para a hermenêutica tradutória. A terceira parte relata a história da hermenêutica filosófica como a fundação legítima da hermenêutica tradutória. Na quarta parte, devotada às "perspectivas futuras", tentará reforçar a legitimidade da abordagem hermenêutica, demonstrando como é abonada por resultados de pesquisa em ciência cognitiva. Para motivar a continuidade dos trabalhos em hermenêutica filosófica, também oferecemos uma metodologia para o estudo do processo tradutório baseada nos princípios hermenêuticos. Finalmente, oferecemos um exemplo de legitimação do a solução criativa de problemas, baseado na abordagem hermenêutica de um problema de tradução, validada nos resultados da pesquisa cognitiva. Palavras-chave: Hermenêutica tradutória. Subjetividade em tradução. Criatividade em tradução. Estudos da tradução. Ciência cognitiva. 
La pertinence d'une théorie de la traduction se mesure à la façon dont elle gère la créativité

Stefanink and Bălăcescu, 2015, p. 600

\section{Why do we need the hermeneutical approach in translation studies?}

Thesis: Because it is the closest thing to an ideal translational practice which focuses on translating meanings, not words.

Characteristics: What fundamentally characterizes hermeneutics is the fact that it integrates subjectivity, corporeality and creativity in its theoretical reflection.

\subsection{Subjectivity}

Translational hermeneutics has integrated the subjectivity of the translator in its theoretical approach, because it is unavoidable. Recent results in cognitive research have proved this undeniably. For instance, the neurophilosopher Hans Lenk (2014) has shown that, when we perceive an object, our brain decomposes it before it synthesizes it in order to bring it to our understanding. Some areas of our brain register the size of the object, others the colour etc. If I see a golden delicious, which is a very common apple in Europe, I register its form, its colour, eventually its smell, its weight, in different areas of my brain, and my brain associates it with the category apple, and saves it in this category. This is a process of categorization: "Understanding means categorizing" (LAKOFF, 1987, p. 5).

But what are these categories in our mind? They are the result of our vécu, which is the result of our recurrent experiences in everyday life. It is like a forest path. Once you have cleared a path through the jungle, next time, you will use the same path, even if it is a little detour, since the path is cleared, and you don't have to fight once again against the thicket of the forest to have your path made. Empirical experiments have shown that this is the way the brain reacts and influences human behaviour. 
In our brain, this path is the neural pathway by which the neurones bring information to the brain. The more you use the same neural pathway the stronger it becomes and transforms itself into an engram, that means a memory trace [Gedächtnisspur]. As connexionism (SCHADE, 1992) teaches us: it is the frequency of the repetitions that strengthens the pathway. These different pathways form a neural network, based on our personal experiences, through which we perceive the incoming information.

So, this neural network biases and influences our perception by associations with our déjà vécu. This can be observed in a very simple experiment, related by Fillmore (1976, p. 62) . A teacher relates such an experiment. She came into the classrom with a grapefruit, and started peeling it by detaching fine slices of the peel. When she had finished this operation she asked the students what the fruit she had peeled was. The answer was that it was an orange. This means that the students had interpreted her action through what knowledge they had of handling fruits. For them, obviously, a grapefruit was something that you cut in half with a knife and eat with a spoon. And Fillmore (1976, p. 62) concludes: "The categorizing function of the words had not yet been liberated from the scene of people in their experience eating the fruit".

Even this simple example shows that we are interpreting when we try to understand, and that this interpretation is subjective, in this case linked to cultural habits, Bourdieu's (1980) habitus. This example also supports the hermeneutical idea of the way we are acquiring meaning: by categorizing (BĂLĂCESCU and STEFANINK, 2006).

We have here one aspect of the hermeneutical circle: in order to understand, we must already have an idea of the new object we are seeing or the new information we are getting, in order to categorize it, categorization being the basis of the understanding process, otherwise, if we have not the slightest clue, we will not be able to understand. This neuronal network which biases our perception is, of course, subjective. 
For translators, this means that, when they try to understand the text, they unavoidably project already some fore-understanding on the text. Heidegger calls this fore-understanding a Vorverständnis, the cognitivists use the term script. Translators unavoidably approach the text with such a fore-understanding in their minds. This fore-understanding is, of course, unavoidably liable to change in the course of reading. The more the translators progress in the text, the more this preconceived meaning becomes complete, that means in harmony with what the text really means to them. German translatologist Radegundis Stolze (2015) introduces the term Stimmigkeit to describe this harmony. For the hermeneutic translator, the translation is complete or stimmig when the target text corresponds to the mental representation of the meaning in the translator's brain.

This hermeneutical conception is supported by cognitivistic research as, for instance, Fillmore's (1976, p. 61) description of the process of understanding shows:

\begin{abstract}
The first part of the text activates an image or scene of some situation in the mind of the interpreter; later parts of the text fill in more and more information about that situation, give it a history, give it a motivation, embed it in other scenes or situations, and so on. In other words what happens when one comprehends a text is that one mentally creates a kind of world; the properties of this world may depend quite a bit on the individual interpreter's private experiences a reality which should account for part of the fact that different people construct different interpretations of the same text
\end{abstract}

Fillmore's former example, in which he draws the conclusion from the orange/grapefruit experiment, implies that, in his conception, the words which we store in our brain during the process of knowledge acquisition are extracted from the scenic context and stored independently. A conception which will lead over to the MOPs theory (SCHANK, 1982), which is so important 
in our endeavours to understand creativity in the translation process, as shown below.

\subsection{Creativity}

Another aspect of the translator's everyday life, which is often left aside by translation theorists is creativity. Hermeneutics show that creativity is nothing mysterious, but a problem-solving activity to overcome cultural barriers. If a theory excludes this creativity from its considerations because it is not systematizable, as some theoreticians do (GERZYMISCH ARBOGAST AND MUDERSBACH, 1998, p. 16), they induce the insecurized translator to abandon brilliant metaphorical creative solutions in favour of logically more admittable, but communicatively paler and less expressive solutions, using a "playing-it-safe" strategy to avoid criticism, because they would not know how to meet this criticism. Hermeneutics helps you to dispel this criticism. Hermeneutics thinks that these "playing-it-safe" translations very often betray the original texts because they are missing the "tone" of the text (KOHLMAYER, p. 2015).

Moreover, using the results of recent research in cognitive sciences, hermeneutics encourages your creativity to solve translation problems by making use of what cognitivists call lateral thinking (DE BONO, 1970) or divergent thinking (GUILFORD, 1975), which can be trained and helps the translator to find solutions to overcome the problems created by cultural barriers.

\subsection{The Epistemological Value of Metaphors}

And to this purpose of encouraging creativity, hermeneutics also makes use of what cognitive science has discoverd about the epistemological value of metaphors. Sometimes, the meaning that is "between the lines", as Schleiermacher says, can better be communicated by using metaphors. Hermeneutics legitimizes the use of metaphors. 
Hans-Georg Gadamer has discussed how metaphor might be retrieved from the Aristotelian canon and re-examined as a gateway to interpretation that casts light on the act of knowing itself. In his account, two types of meaning allow us to oppose a rhetorical conception of metaphor to another conception that expresses a spontaneous relationship to what we know. Metaphor in this account is not simply a-theoretical seeing but introduces "seeing as" into the process of cognition itself (HEIDEGGER, 2008, pp. 189-92). This epistemological value of metaphor is confirmed by cognitive research as we have shown (B口L $\square \mathrm{CESCU}$ AND STEFANINK, 2006, p. 60 et passim).

Let us see what Lakoff and Johnson (1980) have to offer. The metaphor theory of Lakoff and Johnson can provide the translator with a valuable legitimation basis for his creative problem-solving. They assume the following:

1. Categorizing is the basis of each understanding process: "In order to understand the world and function in it, we have to categorize" (ibid., p. 162).

2. This categorization takes place on the basis of "recurrent experience" ("recurrent experience leads to the formation of categories", ibid., p. 230), which leads to the formation of metaphors: "much of our conceptual system is structured by metaphor" (ibd., p. 147), "our conceptual system is inherently metaphorical” (ibd., p. 184).

3. It is essential to categorizations that they emphasize certain aspects of experience to the detriment of others: "A categorization is a natural way of identifying a person or object of experience by highlighting certain properties, downplaying others, and hiding still others" (ibid., p. 163).

4. This allows us to come to a new understanding of our experiences: "Such metaphors are capable of giving us a 
new understanding of our experience [...] highlighting some things and hiding others" (ibid., p. 139).

5. These metaphors are interlinked: "metaphors allow us to understand one domain of experience in terms of another. This suggests that understanding takes place in terms of entire domains of experience and not in terms of isolated concepts" (ibid., p. 117). "[C]onceptual metaphors are grounded in correlations within our experience" (ibid., p. 154-155).

6. The metaphor network which structures our understanding of the world is different from culture to culture, because of the different ecosystems: "But the human aspects of reality are different. [...] The conceptual systems of different cultures have depended on the physical environment they have developed" (ibid., p. 146). "Our experiences will (1) differ from culture to culture" (ibid., p. 154), and (2) may depend on our experience in terms of another, that is, our experience may be metaphorical in nature.

Don't we have here the basis for the comprehensibility of associative-creative problem-solving strategies in translation? Connectionism and metaphor theory confirm each other, inasmuch as our recurrent experiences, which lead to the formation of categories necessary for the process of understanding, are reflected in connectivistically activated (and thus intensified) neuronal pathways (or engrams), which are used in priority by new experiences (in technical terminology: fired, SCHADE, 1992, p. 11), which leads to further reinforcement.

On the linguistic level, these recurrent experiences are reflected as phraseological metaphors. However, our experiences are not stored in isolation, but - as seen from the point of view of connectivity - in dynamically networked paths, which are the "metaphorical entailments" that form the entire conceptual network 
with which we understand the world. These mutually confirming associative connections at the neural as well as at the conceptual level legitimize associative thinking as a problem-solving strategy. And if we accept Paul Valéry's conception of a work of art as being left over to the understanding of the recipient when it has left the artist's hands, then every creative translation - like every new metaphor - is a "highlighting" in the sense of Lakoff and Johnson (1980) of aspects of the original which have hitherto been hidden and which can lead to a new understanding of this original (point 4) from the target-cultural perspective (in the sense of Bachelard, Derrida, Mavrodin and other representatives of Poietics). The material basis of metaphorically networked experiences can be found in the abovedescribed neural pathways or engrams of our brain.

We should not forget that, long before the cognitivists draw attention to the epistemological power of methaphor, Percy Bysshe Shelley anticipated this power of metaphor. For him, all language is basically poetry rather than simply a means of communication. Shelley claims that language was originally poetry by virtue of its prophetic power to express a vital relationship to the world, an idea which also underlies Heidegger's hermeneutic conception of language. When relying on Heidegger's reading of Kant and the role he attributes to imagination, we can view the figure of the torch-bearer in Shelley's Prometheus Unbound as a metaphor for how the poet passes between the spheres of prophesy and cognition, while translating experiences that otherwise would remain opaque and limited.

And when he claims that literary myth is an advanced form of metaphor, Shelley is forecasting another hermeneutic idea which we find in Paul Ricœur's conception of the role myths should play in understanding the world. The "hermeneutic turn" in Ricœur's philosophy, in the sixties of the twentieth century is due to his will as a protestant philosopher to explain the evil in the world. This is the origin of his developing a theory of interpretation which is fundamental for philosophical hermeneutics, and which contributes fundamentally to form the basis of the hermeneutical approach in translational hermeneutics. For Ricœur (2010), metaphor is 
"the central problem in hermeneutics" and there exists a "vérité métaphorique" [metaphorical truth] (1975, pp. 11, 310).

\subsection{The Corporeality of our Understanding}

Another fundamental of hermeneutics that is integrated in its theoretical approach is the corporeality of our understanding. Our empirical research, based on ethnomethodological conversation analysis, reveals an amazing emotional effect exercized by elements of the source text which appeal to the senses of the reader/translator. Understanding the meaning of a text with the senses is something that we commonly admit and expect in poetry. But it is not limited to poetry. We also find it in other text types. It is one of the devices that authors may use to make their texts more convincing, acting on our feelings, on our emotions and on our sensuality. This may sometimes lead to translations that are not always easily accepted by logical intellectual thinking. But hermeneutics integrates this corporeality of understanding in its theoretical approach, and endeavours to give it a scientific basis. Moreover our empirical research reveals that very often translators do not realize what triggered their creative problem-solving. The hermeneutic approach helps them to analyze how much their creative understanding of the text and their creative solutions owe to their somatics, as we hope to have convincingly tried to show in Stefanink and Bălăcescu (2017). Now, let us see in what scientific context the hermeneutical approach developed itself.

\section{The scientific context of tanslation studies in the 1970s, when translational hermeneutics where introduced: translating words vs. Translating meanings}

When reading a text, we do not read words; instead, we try to grasp the meaning of a text. In addition, there is a difference between a normal reader of a text and a translator. The normal 
reader acquires the meaning intuitively. The translator has to go further and make this intuitive understanding explicit in order to translate it (Heidegger's Auslegung [explicitation]). Translational hermeneutics is trying to find a methodology to get at this meaning and to make it explicit.

But: Where is the meaning?

\subsection{The gradual evolution from an atomistic to a holistic} view of meaning in conformity with the evolution of the translation unit.

When translation theory started to develop systematically in the second half of the $20^{\text {th }}$ century, the meaning was obviously considered as depending on the translation unit.

If we consider the evolution of translation theories in the second half of the past century we clearly see that the meaning is not in the words. On the contrary: we observe a development starting with an atomistic view, (which was trying to find the meaning by dissecting the words into their minimal units of signification), and moving more and more towards a holistic approach. This holistic approach is one of the fundamentals of translational hermeneutics.

\subsubsection{The structuralist approach: the word as translation unit}

The structuralist approach which aimed to develop a model for machine translation tried to seize the meaning of words by decomposing these words in their semantic elements. Kade, the most influent translatologist in the $1960 \mathrm{~s}$, went so far as to pretend that the process of understanding was not necessary, and should be avoided since it implied the subjectivity of the translator (KADE, 1968, p. 58). The act of translation consisted of finding one or more words in the target language which would represent the same semantic features. So Eugene Nida, the famous Bible translator, wrote: "What we do aim at is a faithful reproduction of 
the bundles of componential features" $\left(1974\right.$, p. 50) ${ }^{1}$. And Georges Mounin, the French linguist, compared translation to chemistry, which broke down organic entities into their elements in order to reconstruct them synthetically by assembling these elements into a new entity. In Problèmes théoriques de la traduction, he wrote: "Si de telles 'particules de sens' [minimales] existaient, la traduction deviendrait quelque chose d'aussi simple que l'analyse et la synthèse en chimie" (MOUNIN, 1963, p. 97).

But the ALPAC (Automatic Language Processing Advisory Committee) which evaluated the results of this research cancelled this program (in 1966), because it was not efficient. There were too many misunderstandings with the results of machine translation. The meaning of the text could not to be grasped this way.

\subsubsection{The Pragmatic Approach: The Sentence as Translation Unit. A first step for the translator not to find the meaning in words}

After this failure, the translatologists considered that the problem was one of translation units. The word as translation unit was not enough. The research extended to the sentence as translation unit. And the English linguist John Catford said the translation unit is the sentence, as a self-contained unit conveying the meaning:

In total translation, SL and TL texts or items are translation equivalents when they are interchangeable in a given situation. This is why translation equivalence can nearly always be established at sentence-rank - the sentence is the grammatical unit most directly related to speech function within a situation. (1965, p. 49)

\footnotetext{
1 Eleven years later Nida, will distance himself from this word-centered vision of translation: "We are no longer limited to the idea that meaning is centered in words or even in grammatical distinctions. Everything in language, from sound symbolism to complex rhetorical structures, carries meaning” (NIDA, 1985, p. 119).
} 
The outcome of this was, for instance, the stylistique comparée of Vinay and Darbelnet, trying to find sentence structures that might have automatic correspondents in the target language. Another outcome was the speech act theory, which, for the translator, meant that he did not have to stick to the words of the text, but that he had to translate the intended meaning depending on the special situation, which was a first step to consider that the meaning was not in the words but in something beyond the words.

\subsubsection{The text as Translation Unit. The "übersetzerrelevante Textanalyse" (Translator-relevant-Text-Analysis) (HÖNIG, 1989). The Theory of Isotopies. The Functional Approach: "Skopostheorie" (REIß and VERMEER 1984)}

As Linguistics developed into text linguistics, initiated by the German linguist Harald Weinrich, there were many new impacts on translation theory. One very obvious outcome was the skopostheory, which situated the translator as an actor in a social environment (according to the action theory). According to the Lasswell formula, the translator had to take into consideration the "5 Ws": Who is translating what to whom, in which channel with what effect.

This was one more step away from the word, as a translation unit which was supposed to reveal the meaning that the translator was supposed to translate.

Another, more significant step was Algirdas Julien Greimas' theory of isotopies, which he developed in a book published in 1966 with the title Sémantique structurale [Structural Semantics]. His idea was that a word was not isolated in the text, but that it had friends, that are linked between themselves, or, as the German philosopher, Ludwig Wittgenstein puts it: in a text there are words belonging to the same family, they have Familienähnlichkeiten [family resemblances].

For Greimas, this meant they had one or more semantic features in common, which for him were the semantic components as 
minimal units of meaning, the "semes". Nowadays, we can extend this idea of common minimal units to a more general resemblance, and speak, for instance, of an isotopy of irony in a text, that is based on an assembly words conveying this meaning.

Greimas' theory of Isotopies was an important step on the way to translational hermeneutics. With the isotopy theory, the meaning of a word has to be considered in relationship to the other words which are part of the same isotopy. And the meaning of the text emerges from the network of isotopies which structure the text. Following Schleiermacher's statement of the meaning being "between the lines" (Schleiermacher, 1977, p. 315) (we might say that the meaning is "between the isotopies of the text" (Stefanink and Bălăcscu, 2017). And, going one step further, we can say that the meaning is in the "orient of the text" (RICECUR, 1975, p. 156), and that it rises under the eyes of the reader. This is the meaning that the translator has to translate, a meaning that is not linked to special representative words in the text as for instance Gerzymisch claims:

We cannot translate the "despair" in [the short story] Lenz by Georg Büchner (unless it appears as a tangible expression), we need for translation a manifestation of the despair as a concrete expression, that we may transport. It is only the expression that we can 'trans'-port" (GERZYMISCH, 2013, p. 74).

In order to grasp this meaning, which is between the isotopies of the text, we have to interpret the tokens which are likely to bear meaning.

And this is what translational hermeneutics is about.

Let us see now, how the need for hermeneutics developed in the course of history. 


\section{Hermeneutics: Science or Art?}

Hermeneutics can be defined as the science or art of interpreting. Translational hermeneutics is intimately linked to philosophical hermeneutics in so far as translation can be seen as actualized hermeneutics and vice-versa. Schleiermacher's translation of Plato was the godfather of his philosophical hermeneutics. The fundamental problem in philosophical as well as in translational hermeneutics is its legitimation with regard to "objective" criteria as we are familiarized with in natural sciences. So the history of hermeneutics can be seen as a fight for recognition as a science or as rejecting these efforts, and seeing it rather as an art. But things are not clear at all. Even Heidegger (1959: 98) avowed hermeneutics to be "rätselhaft" [enigmatic], and some hermeneuts never gave a clear statement about this, often tending to become inclined to change in favour of the category art in the course of their research, like even the emblemic representant of hermeneutics, Friedrich Schleiermacher, who gave more and more importance to Divination towards the end of his life.

\subsection{From domain-specific isolated aggregates of interpretation rules to methodological universality}

The status as a science is linked to the development of a methodology that might be universally applicable. The first to fight for universality was Johann Conrad Dannhauer. Before Dannhauer, text interpreting existed, closely linked to the translation of ancient texts from Latin and Greek which alimented medieval thinking. But these interpretations were strictly domain specific, concerning religion, philosophy, history, law, medecine, etc. Starting from the observation that with the multiplication of writings due, on the one hand, to the invention of printing and, on the other, to the Renaissance idea of disseminating knowledge, which had as a consequence that scientists became more and more involved in reading, Dannhauer saw the necessity of a universal method of 
interpreting written texts, which he developed as soon as 1630 in a text - Idea boni interpretis et malitiosi calumniatoris - where he introduced the neologism hermeneutica, probably derived from the title of Aristotel's Peri Hermeneias.

His initiative was pursued in the 18th century, when the discussion on universal hermeneutics went into details like discussing the origins of obscurity in difficult passages (Johann Martin Chladenius, 1710-1759) or extending the idea of hermeneutic universality to general semiotics (Georg Friedrich Meyer, 17181777) considering everything in this world as being a sign which pointed towards something behind it that was part of a coherent whole designed as such by the Divine Creator.

In the 19th century, hermeneutics were dominated by a philosopher and theologian who is generally considered as the founder of modern hermeneutics: Friedrich Schleiermacher. He actually "reinvented" hermeneutics in its universal character, seemingly not having had any knowledge about his predecessors in universality, as may be deduced trom a letter to his friend Ehrenfried von Willich, when he started lecturing about hermeneutics in 1805, saying that he could not find any documents concerning the universal character of hermeneutics, but only isolated aggregates of rules focussed on the different scientific or religious domains.

Besides his insistance on the universal character of hermeneutics, Schleiermacher's merit was to extend the interpretative act to the whole of the text. Before him the interpretation was limited to the obscure passages of the text. Now, in his "hermeneutics of misunderstanding", the whole text becomes liable to be misunderstood, and has to be interpreted, the misinterpretation of difficult passages being prepared by the misunderstanding of anterior passages.

Schleiermacher's philosophical hermeneutics were nourished by his translation of Plato and the problems it brought along, which he discussed in his correspondence with Schlegel, trying to draw theoretical insights from the translation practice, and letting his practical translation work benefit from these insights. Thus, for the 
translator, Schleiermacher's merit was to make this philosophical insight relevant for translation theory. It is based on what Gadamer, quoting Augustinus, calls the "inner word" [verbum interius], which is a meaning that is in us and that struggles to be expressed. This meaning is always beyond the words with which we try to express it. As a consequence, no expression of this meaning by words can be seen as the ultimate representation of it. There is as Heidegger will formulate it later - a Sinnüberschuss [surplus of meaning] in every text. This is one of the fundamentals in hermeneutic thinking.

For the translator, this means that there is not such a thing as the perfect translation of the source text. There are only subjective tentative versions corresponding to the mental representations of the meaning in the translator's mind at a certain moment. This mental representation of the meaning is the verbum interius of the translator which struggles to be expressed in words of the target language. Schleiermacher's followers, like Wilhelm Dilthey (1833-1911), endeavoured to overcome this subjective character by developing a methodology for the investigation of meaning that was supposed to guarantee objectivity in human sciences just as analytic thinking did in natural sciences.

\subsection{Contemporary issues in the Hermeneutics Debate}

Hans-Georg Gadamer (1900-2002), however, completely dispelled the idea of such a methodology. For him, the task of hermeneutics was not to find a methodology, but to discover the truth, be it through language or through works of art. The main obstacle to this discovery are our prejudices. The rationalist philosophies have condemned prejudices, conceiving them as something negative. For Gadamer, however, prejudices are part of the process of understanding as something unavoidable that has to be integrated into the theoretical approach. Prejudices hinder our quest for truth when they are ignored. Thus, for Gadamer, the road to truth goes through dialogue, one of the fundamentals 
of Gadamer's hermeneutics. In the dialogue with the other, we become conscious of our own prejudices, and we have the possibility to revise them and integrate the truth of the other into our own vision, in a process which Gadamer calls a "fusion of horizons". This reminds us of Berman's or Ricœur's conception of translation as an act of "hospitality" to the foreign otherness. For Gadamer, understanding is a permanent dynamic progress in a dialectic confrontation with the other.

For the translator, this "other" is the text. The translator has to enter into a dialogue with the text. Gadamer takes over Wittgenstein's game metaphor and describes the reader as one who has to enter the game in order to understand the meaning, he has to get more an more involved in the course of his reading. Where Schleiermacher said that "the meaning is between the lines", Gadamer says the meaning is "behind the words". To get at it we have to develop empathy (though Gadamer himself never used this term himself). Meaning is not anything static to be seized by mere intellectual analysis.

An example for such a positive integration of prejudice into a positive construction of meaning during a translation process is given in Stefanink and Bălăcescu (2015).

All these ideas are made fruitful for translation by Fritz Paepcke, whose conception of translation, taken over from Gadamer, materializes itself in a dynamization of the terminology of translation studies speaking for instance of Kommmunikationsgeschehen [the happening or process of communication], Wahrheitsgeschehen [the happening or process of truth], etc, to draw attention to the dynamic character of meaning. Paepcke introduces terms like the Leibhaftigkeit [corporeality, sensuous physicality] of the translator in his understanding, insisting on the physical implication of the translator with all his senses, an aspect which Douglas Robinson (1991) will sum up under the term somatics.

With Paepcke, the translator as a human being was brought into the focus of attention, which, in the context of all-dominating linguistic structuralism, was indeed a little revolution in translation 
studies. Fundamental requirements of the translator's activity, like "intuition" and "creativity", which had been explicitely banned from theoretical thinking because they "did not lend themselves to a systematic approach" (Gerzymisch-Arbogast and Mudersbach, 1998, p. 16), were suddenly introduced into theoretical thinking with Paepcke's conception of translation. More so, their status in a translation theory became a touchstone for the validity and quality of a theory and its relevance for practitioners of translation (Stefanink and Bălăcescu, 2015, p. 600).

However, the impossibility of handling intuition and creativity from a systematic point of view gave rise to concerns about the danger of subjectivity in translation and the lack of scientificity which was suspected to go with it. Instead of trying to deny the subjectivity of the translator, the hermeneutic approach deliberately integrated it in its theoretical thinking. But handling intuition and creativity compelled the hermeneuts to look for new scientific criteria in the quality assessment of translation.

Radegundis Stolze, Paepcke's disciple in hermeneutics, recurred to linguistics in order to bring some fundamental structure into the disseminated - sometimes not very clearly formulated or even contradictory - ideas which went along with Paepcke's examples of hermeneutic translation. In her different books about hermeneutics and translation, she highlightens several concepts of philosophical (mainly Gadamerian) hermeneutics, and explains their relevance for the translator. She insists on the holistic character of the process of understanding in which the meaning "überwältigt" [overwhelms] the translator, bringing him to solve translation problems in an autopoietic half unconscious intuitive formulation impulse in the target language. This does not hinder her to introduce a didactics of translation based on "fields of attention" which will guide the translator in the execution of his task.

But the handling of intuition and creativity, which is the core issue in translational hermeneutics, exacted a view beyond the borders of linguistics into the new fields of cognitivistic research. 
If, according to Heidegger, "words grow into meaning" ["Den Bedeutungen wachsen Worte zu"], then hermeneutic translation is condemned to creativity. If the meaning is "between the words", translating consists in a deverbalization process, as proclaimed by the interpretative theory defended by the School of Paris, and a reformulation in the target language, which culminates in more or less creative solutions, trying to "crystallize" (Stefanink and Bălăcescu, 2017) into new words the meaning that had grown between the isotopies of the source text in the process of interpreting, as can be deduced from the observations made about the translation process with the help of an empirical, corpuscentered methodology taken over from American sociologists and introduced into the hermeneutic approach by Stefanink (1995): the ethnomethodological conversation analysis.

The introduction of subjectivity, intuition and creativity as fundamentals in hermeneutic translation studies gave rise to concern regarding the scientific character of the hermeneutic approach. For non-hermeneutic "objectivists", scientificity was linked to the "traceability" of the different steps taken to achieve a result. According to them, this traceability was lacking in the hermeneutic approach (GERZYMISCH, 2013, p. 73). This position, however, ignores the efforts of recent research towards a Verwissenschaftlichung [scientification] (CERCEL, 2013, pp. 122-149) of translational hermeneutics. Indeed Popper (1966, pp. 7-8) does not limit the scientific character of a method to the predictability of the results (which would deny scientificity to inventors); no, Popper says that the scientific character of research is guaranteed by a methodology a posteriori, if the inventor can trace back and explain the different steps that led to the invention. This is what recent research in translational hermeneutics is striving to do by appealing not only to linguistic analysis, but also to recent research in cognitive studies.

The methodology for this new aproach was provided by American researchers in social sciences in the 1970s as described by Garfinkel (1984): ethnomethodological conversation analysis, 
as used in the domain of ethnoscience. It consisted of studying the naive representations that the common language user vehiculated behind the words s/he used, especially when talking about things of everyday life which triggered her/his imagination, as for instance "the woman and men in white", which became a field of investigation for ethnomedecine. Stefanink (1995) introduced this methodology into translation studies under the French name of ethnotraductologie [ethnotranslatology]. It consists of two or more translators who "negociate" a translation with the aim of reaching a common version in the target language on which they agree. This methodology provides not only a possibility for studying the process of translating but also exposes the naive representations the implicated translators have in their minds regarding the process of translation, language and the relationship between culture and language, etc.

It is moreover very efficient from a didactical point of view. After having transcribed their dialogue the participants analyze it with the help of their supervisor, an analysis in the course of which they are confronted with their naive ideas about about the process of translation, about language, about the relationship between culture and language, etc. This bringing into consciousness is very efficient and convincing as shown in Bălăcescu/Stefanink 2003 where a group of translators from French into Corsican language who refused any theoretical approach were shown that at the back of problem-solving there was some elements of theory, scattered and disconnected, at random, but responsible of heir decision making.

These new elements in translation theory require new criteria for quality assessment. Where analytic approaches could rely on (seemingly) logic and rational steps leading to (an illusive) "objectivity", the hermeneutic approach relies on what is called (in the socio-philosophical studies of Jürgen Habermas) konsensuelle Wahrheit [consensual truth]. For the translator this means that he has to provide "intersubjektive Nachvollziehbarkeit" [intersubjective plausibility/traceability] (STEFANINK, 1997), he has to convince the "experts" (RISKU, 1998), his peers, in his domain 
of the validity of his translation, especially where creative solutions have been necessary.

\section{An Example of a Creative Hermeneutic Problem-Solving Sustained by Cognitive Research}

German students had to translate from English into German in a context describing the problems of young couples having children and being both working in a job:

They had to juggle two careers and a potty-chair The students translated potty-chair by

1. Windelwechseln (changing the diapers): two careers and changing the diapers

2. Kind (child): two careers and the child

What happened? In the English context of child education, the word potty-chair triggers a very common element, which is lexicalized in idiomatics like potty-chair training. According to the scenes and frames semantics of Charles Fillmore (1976), the linguistic frame potty-chair triggered, in the mind of the translator, the "scene" excrement management. Eleanor Rosch (1973) tells us that, in every category, you have an element that is prototypical for the category, and the figure/ground alignment theory of another cognitivist, Ronald Langacker (1987), tells us that the relationship between this prototypical element, which he calls figure, and the background, which he calls ground, can change and is different from one culture to the other. In England the prototypical emblematic element in this scene is the potty-chair, in Germany it is changing the diaper. According to the cognitivist Roger Schank (1982), both are part of what Schank calls MOPs (Memory Organization Packets). The memory of the bi-cultural translator had registered the scene excrement management, this scene contains both the elements of potty-chair and diaper changing. The translator, knowing about 
their difference in the prototypical character in English culture compared to German culture, undertakes the replacements that seem necessary to keep the "Wirkungsgleichheit" [equivalence of effect] (REIß AND VERMEER, 1984) in the target culture.

The translation by Kind establishes the equivalence on a higher level. Indeed, Kind can be seen as a short cut for the scenario Kindererziehung [education of children]. The potty-chair is one of the elements in this scenario of Kindererziehung, so it sounds plausible, according to the Thematic Organization Packets [TOP] theory of Roger Schank, that the translator associates this element of the scene with the scenario of Kindererziehung, which includes this scenic element potty-chair, which belongs to the scene excrement management. The memory organization theory would also have made possible a translating by Fläschchen geben [bottle feeding], because this is another element of the scenario child education. The dots "..." In the following schema indicate other alternative scenes belonging to the scenario child education.

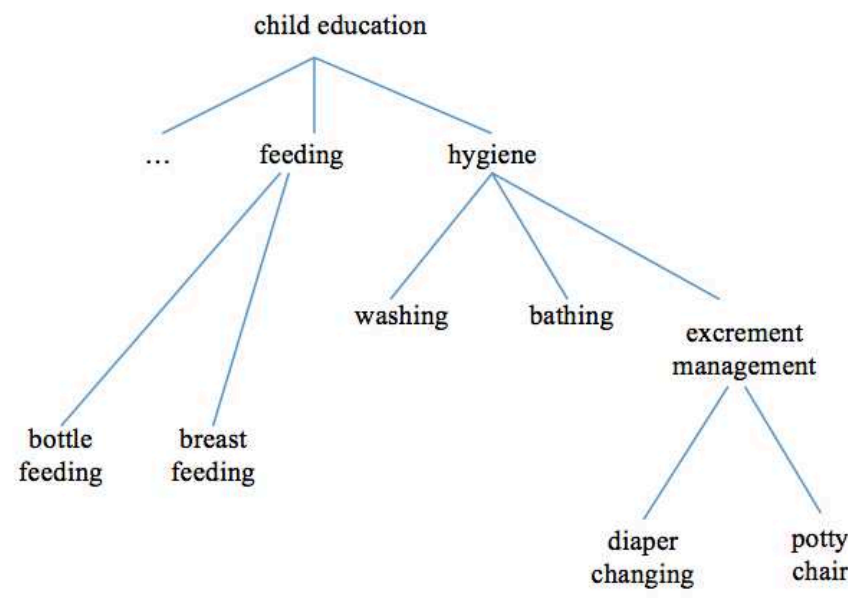

As one can see, the relations between the different scenes are of associative nature, and as Fillmore (1976, p. 64) puts it: "scenes and frames are mutually retrievable, meaning that a scene can activate 
its associated frame and a frame can activate its associated scene". Let us also remember that Fillmore's concept of a "scene" as well as that of a linguistic frame is semantically very wide, offering the translator a wide range of potential neural associative chainings as one way to explain his/ her creative problem solutions:

I want to say that people, when learning a language, come to associate certain scenes with certain linguistic frames. I intend to use the word scene - a word that I am not quite happy with - in a maximally general sense, to include not only visual scenes, but familiar kinds of interpersonal transactions, standard scenarios, familiar layouts, institutional structures, enactive experiences, body image; and, in general, any kind of coherent segment, large or mall, of human beliefs, actions, experiences, or imaginings. I intend to use the word frame for referring to any system of linguistic choices (the easiest cases being collection of words, but also including choices of grammatical rules or grammatical categories) that can get associated with prototypical instances of scenes. [...]

I would like to say that scenes and frames, in the minds of people who have learned the associations between them, activate each other; and that, furthermore, frames are associated with other frames by virtue of shared linguistic material, and that scenes are associated with other scenes by virtue of sameness or similarity of the entities or relations or substances that are in them or their contexts of occurence. (FILLMORE, 1976, p. 63).

All these explanations given by cognitive science legitimate the creativity that helps the hermeneutic translator to overcome the cultural barriers. Hermeneutics says: you have to feel the text, with all your senses, you have to let yourself overwhelmed by the meaning which you feel, and then you have to make it understood to others, for which you need the support of linguistic analysis and cognitive science. Linguistic analysis allows you to see what 
triggered your creative solution from the bottom up elements of the text, cognitive science helps you to understand and make understood to others what associative chaining processes induced this problem solving.

\subsection{Outcoming Perspectives}

Perspectives for the future: a better cooperation between philosophers and translators might be for the benefit of both disciplines. Schleiermacher drew philosophical hermeneutics from his discussion with Schlegel about his translation of Plato. Contemporary translatologists - as for instance, Paepcke - have been feeding on philosophers like Gadamer, but the interest of hermeneutic philosophers in translation is very limited (as we could notice at the last symposion of philosophers in Florianopolis, Hermeneia 2015). Have they forgotten that Schleiermacher's ideas about hermeneutics came from his translation of Plato and his discussions with Schlegel about this translation? Only Paul Ricœur has been pleading for an application of philosophical hermeneutics to the different scientific domains. But until now this has not been very much materialized.

At the end sof her summa, Cercel (2013, p. 364) deplores the lack of recognition that translation hermeneutics is suffering, and invites to further efforts to make it better received. We completely share her criticism, when she writes: "Dazu gehört mehr als plakative Aussagen" [This exacts more than abstract statements], and consider this as an invitation to more empirical orientated research, as exemplified, for instance, in Stefanink and Bălăcescu (2015, 2017).

We think that the challenge of making translation hermeneutics more convincing could be met, on the one hand, at the empirical level, by multiplying individual examples of studies concerning the translation process (especially creative problem-solving) with the help of ethnomethodological conversation analysis, which would offer a solid basis to discussions about the contentiously discussed 
comprehension process - actio vs. passio (CERCEL, 2013, p. 153), the role of intuition, etc. - and would put some flesh on the skeleton of fundamental formulations like Heidegger's "Den Bedeutungen wachsen Worte zu" [Words grow into the meanings]. This is what we tried, for instance, in Stefanink and Bălăcescu (2015, 2017).

On the other hand, an interdisciplinary contact with cognitive sciences would be helpful, since cognitive sciences are confirming the heuristic function of hermeneutics. What else is indeed the cognitivist "bottom up/top down" process if not the Gadamerian Horizontverschmelzung, what Schank's (1982) cognitivistic script if not the hermeneutic fore-understanding, Heidegger's Vorverständnis? And Gadamer's plaidoyer for a positive use of this Vorurteil in the comprehension process can be found in Lakoff's (1987, p. 5) ideas about categorization. As for the incriminated "subjectivity" of the hermeneutic approach, linked to the hermeneutic circle, its unavoidability is convincingly proved by the neurophilosophical research of Hans Lenk's (2014, p. 78) in Schemainterpretationismus.

The recent creation of a research center on "Hermeneutics and creativity" at the university of Saarbrücken three years ago, as well as the recent creation of the TRACO [Translation and Cognition] research center at the Johannes Gutenberg University in Mainz/Germersheim (2016) can be considered as an institutional materialization of this interdisciplinary trend and comes as a confirmation of our research in this field. 


\section{References}

AITCHISON, Jean: Words in the Mind. An Introduction to the Mental Lexicon. Oxford: Blackwell, 2003.

BĂLĂCESCU, Ioana; STEFANINK, Bernd (2003). Une approche théorique pour la traduction. In: THIERS, Ghjacumu (ed.). Baratti. Commentaires et réflexions sur la traduction de la poésie. Albiana - Bu - Ccu - Iitm.S. 2003. pp. 24-77.

.(2012): De la valeur heuristique du terme dans l'approche herméneutique. In: CERCEL, Larisa; STANLEY, John. Unterwegs zu einer hermeneutischen Übersetzungswissenschaft. Radegundis Stolze zu ihrem 60. Geburtstag. Tübingen: Narr., 2012.

. (2006): Kognitivismus und übersetzerische Kreativität. In: Lebende Sprachen n.2. 2006. pp. 50-60.

. Rev. of Heidrun Gerzymisch: Translation als Sinngebung (Münster: LitVerlag, 2013). In: Lebende Sprachen 59.1, 2014. pp. 188-207.

BOURDIEU, Pierre. Le Sens pratique. Paris: Les Éditions de Minuit, 1980.

BÜHLER, Hildegund (éd.). Translators and their Position in Society: Proceedings of the Xth World Congress of FIT. Wien: Wilhelm Braumüller, 1985.

CATFORD, J. C. A Linguistic Theory of Translation. An Essay in Applied Linguistics. London, 1965.

CERCEL, Larisa. Übersetzungshermeneutik. Historische und systematische Grundlegung. Saint-Ingbert: Röhrig, 2013.

COSERIU, Eugenio. Einführung in die Textlinguistik. (org. and ed. V. J. Albrecht). Tübingen: Narr., 1980. 
DE BONO, E. Lateral Thinking. A Textbook of Creativity. London: Ward Lock Educational, 1970.

DURIEUX, Christine. Vers un théorie décisionnelle de la traduction. Revue LISA, vol.III, n.3, 2009.

FILLMORE, Charles. Scenes-and-Frames Semantics. In: ZAMPOLLI, Antonio (dir.) Linguistic Structures Processing, Amsterdam: N. Holland, 1976. pp. 55-88.

GADAMER, Hans-Georg. Wahrheit und Methode. Grundzüge einer philosophischen Hermeneutik. Tübingen: J.C.B. Mohr, 1960.

GARFINKEL, Harold. Studies in Ethnomethodology. Cambridge: Blackwell, 1984.

GERZYMISCH-ARBOGAST, Heidrun (1994): Übersetzungswissenschaftliches Propädeutikum. Tübingen: Francke (UTB 1782)

GERZYMISCH-ARBOGAST, Heidrun; MUDERSBACH, Klaus. Methoden des wissenschaflichen Übersetzens. Tübingen: Francke, 1998.

GERZYMISCH, Heidrun (ed.). Translation als Sinngebung. Münster: LitVerlag, 2013.

GRONDIN, Jean. Einführung in die Hermeneutik. Darmstadt: Wissenschaftliche Buchgesellschaft, 2001/2012.

GRONDIN, Jean. Paul Ricœur. [Que sais-je ?] Paris: PUF, 2013.

GUILFORD, Joy Peter. Creativity: A Quarter Century of Progress. In: TAYLOR, Irving A.; GETZELS, Jacob W. (eds). Perspectives in Creativity, Chicago: Aldine, 1975. pp. 37-59.

HABERMAS, Jürgen. Moralbewußtsein und kommunikatives Handeln. Frankfurt am Main: Suhrkamp, 1983. 
HEIDEGGER, Martin (2008): Being and Time (transl. John MacQuarrie and Edward Robinson). New York and London: Harper and Row, 2008.

. Sein und Zeit. Tübingen: Niemeyer, 1927/1967.

. Unterwegs zur Sprache. Pfulligen: Neske, 1959.

HÖNIG, Hans. Die übersetzerrelevante Textanalyse. In : KÖNIGS, Franck (ed.). Übersetzung und Fremdsprachenunterricht. München: Goethe-Institut, Ref. 42 Arbeitsstelle für wissenschaftliche Didaktik. 1989.

IONESCU, Tudor. Le traducteur herméneute. In: IONESCU, Marina Mureşanu. Actes. Journées de la francophonie. IVème édition, Iaşi: Editura universităţii "Alexandru Ioan Cuza", 1998. pp. 111-114.

. Tudor. Ştiinţa sau/arta traducerii [La science ou/et l'art de la traduction]. Cluj-Napoca: Editura Limes, 2003.

KADE, Otto. Zufall und Gesetzmäßigkeit in der Übersetzung, Leipzig: VEB Verlag Enzyklopädie, 1968.

KANT, Immanuel. Kritik der reinen Vernunft, Werke in zwölf Bänden, Band 3, Frankfurt am Main: Suhrkamp, 1977 (or. publ. 1787).

KOHLMAYER, Rainer. Die Stimme im Text als tertium comparationis beim Literaturübersetzen. In: STOLZE, Radegundis; STANLEY, John; CERCEL, Larisa (eds). Translational Hermeneutics. The First Symposium. Bucureşti: Zeta Books, 2015. pp. 235-255.

KRINGS, Hans Peter. Was in den Köpfen von Übersetzern vorgeht. Eine empirischeUntersuchung zur Struktur des Übersetzungsprozesses an fortgeschrittenen Französischlernern. Tübingen: Narr, 1986.

KUßMAUL, Paul. Kreatives Übersetzen. Tübingen: Stauffenburg, 2000. 
LADMIRAL, Jean-René. La philosophie et la traduction. In: BATCHELOR, Kathryn; GILONNE, Yves (eds). Translating Thought/Traduire la pensée. Nottingham: University of Nottingham, 2010. pp. 6-16.

LAKOFF, George; JOHNSON, Mark. Metaphors We Live By. Chicago: University of Chicago Press, 1980.

.Women, Fire and Dangerous Things. What Categories Reveal about The Mind. Chicago: University of Chicago Press, 1987.

LANGACKER, Ronald W. Foundations of Cognitive Grammar. Stanford: Stanford University Press, 1987.

LENK, Hans. Methodologischer chemainterpretationismus: Erkenntnistheoretisches zur Einführung. In: PAUL, Gregor. Transkulturelle Logik. Universalität in der Vielfalt. Bochum Freiburg: Projektverlag, 2014. pp. 71-98.

MOUNIN, Georges. Les problèmes théoriques de la traduction. Paris: Gallimard, 1963.

NIDA, Eugene A. Translating Means Translating Meaning - A Sociosemiotic Approach to Translating. In: BÜHLER, Hildegund (éd.). Translators and their Position in Society: Proceedings of the Xth World Congress of FIT. Wien: Wilhelm Braumüller, 1985.

. Semantic Structure and Translating. In: WILSS, W.; THOME, G. Aspekte

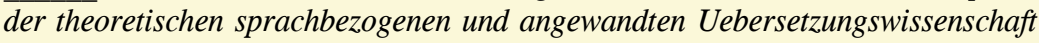
II, Heidelberg: Groos, 1974. p. 50.

O'KEEFFE, Brian. Prologue to a Hermeneutic Approach to Translation. In: STOLZE, Radegundis; STANLEY, John; CERCEL, Larisa (eds). Translational Hermeneutics. The First Symposium. Bucureşti: Zeta Books. 2015. pp. 145-177.

PAEPCKE, Fritz. Übersetzen als hermeneutischer Entwurf. In: Im Übersetzen leben. Übersetzen und Textvergleich: Tübingen: Narr, 1986. pp. 86-101. 
POPPER, Karl R. Logik der Forschung. Wien: Springer, 1966.

REIß, Katharina; VERMEER, Hans. Grundlegung einer Translationstheorie. Tübingen: Niemeyer, 1984.

RICCEUR, Paul. Du texte à l'action, Paris: Seuil, 1986.

. Ecrits et Conférences. II. Herméneutique. Paris: Seuil. 2010.

. La Métaphore vive. Paris: Seuil, 1975.

RISKU, Hanna. Translatorische Kompetenz. Kognitive Grundlagen des Übersetzens als Expertentätigkeit. Tübingen: Stauffenburg, 1998.

ROBINSON, Douglas. The Translator's Turn. Baltimore/London: John Hopkins, 1991.

ROSCH, Eleanor. Cognitive Psychology. Cognitive Psychology, 4, 1973. pp. 328-350.

SCHADE, Ulrich. Konnektionismus: Zur Modellierung der Sprachproduktion. Opladen: Westdeutscher Verlag, 1992.

SCHANK, Roger, C. Dynamic Memory. A Theory of Reminding and Learning in Computers and People, London/New York: Cambridge University Press, 1982.

SCHLEIERMACHER, Friedrich. Hermeneutik und Kritik. Mit einem Anhang sprachphilosophischer Texte Schleiermachers. Suhrkamp: Frankfurt, 1977.

STEFANINK, Bernd; BĂLĂCESCU, Ioana. Le verbum interius du traducteur et la cristallisation du sens. META 62. 2. August/2017. (Forthcoming.) $599-620$

. Les cheminements de la créativité en traduction. META 60.3. 2015. pp. 
STEFANINK, Bernd. 'Esprit de finesse' und 'esprit de géométrie': Das Verhältnis von 'Intuition' und 'übersetzerrelevanter Textanalyse' beim Übersetzen. In: KELLER, Rudi. Linguistik und Literaturübersetzen. 1997. pp. 161-183.

. L'ethnotraductologie au service d'un enseignement de la traduction centré sur l'apprenant. Le langage et l'homme, 4. 1995. pp. 265-293.

STOLZE, Radegundis; STANLEY, John; CERCEL, Larisa (eds). Translational Hermeneutics. The First Symposium. Bucureşti: Zeta Books, 2015.

STOLZE, Radegundis. Hermeneutik und Translation. Tübingen: Narr, 2003.

. The Translator's Approach - Introduction to Translational Hermeneutics. Berlin: Frank \& Timme, 2011.

Recebido em: 20/03/2017 Aceito em: 16/06/2017 Publicado em setembro de 2017 